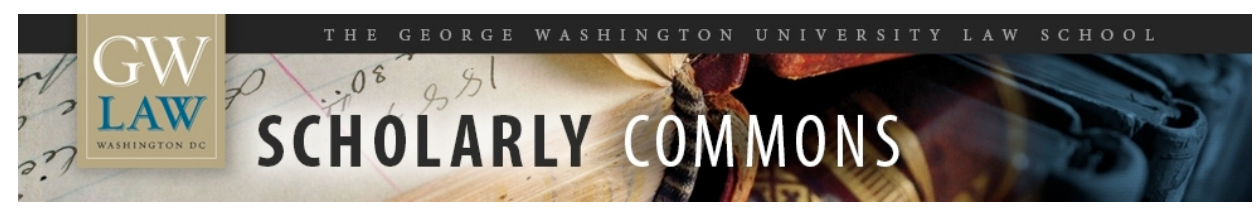

2016

\title{
Regulatory Leveraging: Problem or Solution?
}

\section{William E. Kovacic}

George Washington University Law School, wkovacic@law.gwu.edu

David A. Hyman

Follow this and additional works at: https://scholarship.law.gwu.edu/faculty_publications

Part of the Law Commons

\section{Recommended Citation}

Kovacic, William E. and Hyman, David A., Regulatory Leveraging: Problem or Solution? (August 22, 2016). GWU Law School Public Law Research Paper No. 2016-41; GWU Legal Studies Research Paper No. 2016-41. Available at SSRN: http://ssrn.com/abstract=2817339

This Article is brought to you for free and open access by the Faculty Scholarship at Scholarly Commons. It has been accepted for inclusion in GW Law Faculty Publications \& Other Works by an authorized administrator of Scholarly Commons. For more information, please contact spagel@law.gwu.edu. 


\title{
REGULATORY LEVERAGING: PROBLEM OR SOLUTION?
}

\author{
William E. Kovacic ${ }^{*}$ and David A. Hyman ${ }^{* *}$
}

"Nice merger you've got here.

It would be a shame if anything was to happen to it."

\section{INTRODUCTION}

Worldwide, there are approximately 130 jurisdictions with competition laws. ${ }^{2}$ The governmental entities charged with enforcing these laws are typically called "competition agencies," but many of these entities do things other than competition law. Of the thirty-six agencies listed in the Global Competition Review's 2015 annual review, half have responsibilities beyond their competition portfolio. ${ }^{4}$ The particulars vary from country to country, but a list of the usual suspects would include consumer protection; public procurement; and public utility access, pricing,

* Visiting Professor, King's College London, Global Competition Professor of Law and Policy, George Washington University Law School, and Non-Executive Director, United Kingdom Competition and Markets Authority. From 2006 to 2011, he served as a member of the Federal Trade Commission and chaired the agency from March 2008 to March 2009.

${ }^{* *}$ H. Ross and Helen Workman Chair in Law, University of Illinois Colleges of Law and Medicine. From 2001-2004, he served as Special Counsel at the Federal Trade Commission. The views expressed here are the authors' alone. The authors are grateful to participants in workshops at Heidelberg University, Pembroke College of Oxford University, Rutgers University Graduate School of Management, the University of Amsterdam, and the University of Mannheim for many helpful comments and suggestions.

${ }^{1}$ See Barry Popik, "Nice Place You Got Here. Be a Shame if Anything Happened to It." (July 15, 2009),

http://www.barrypopik.com/index.php/new_york_city/entry/nice_place_you_got_here_be_a shame if anything happened to it (tracing historical usage of the phrase). See also Monty Python's Flying Circus: Army Protection Racket, YouTube, 1:41-1:49 (Nov. 13, 2015) https://www.youtube.com/watch?v=pm5mtpPtW1Q [hereinafter Monty Python].

"Dino: You've . . . you've got a nice army base here, Colonel.

Colonel: Yes.

Dino: We wouldn't want anything to happen to it."

${ }^{2}$ See William E. Kovacic, The United States and Its Future Influence on Global Competition Policy, 22 Geo. MASOn L. REV. 1157, 1158 n.7 (2015) (discussing global expansion in the number of competition agencies).

${ }^{3}$ For example, in a planning document issued in 2011, the International Competition Network describes the creation of the network in 2001 "by 15 competition agencies" and observes that its membership "has since grown to 117 competition agencies."

InTERNATIONAL COMPETITION NETWORK, THE ICN's Vision FOR ITS SECOND DECADE 1 (May, 2011), http://www.internationalcompetitionnetwork.org/uploads/library/doc755.pdf.

${ }^{4}$ See generally Rating Enforcement: The Annual Ranking of the World's Leading

Competition Authorities, 18 Glob. COMPETITION Rev. passim (2015). 
and regulation. ${ }^{5}$ Several competition agencies also have the power to apply broad public interest standards, ${ }^{6}$ or must implement expansive scalable commands, such as the Federal Trade Commission's power to proscribe "unfair methods of competition."7

In previous work, we have examined how the assignment of multiple functions/areas of regulatory responsibility affects governmental agency performance. ${ }^{8}$ Among other issues, we have considered the impact of the mix of assigned tasks (i.e., whether the tasks are substitutes or complements, and whether they aim at consistent ends); the impact of the number and scope of assigned regulatory tasks on the likelihood of capture; and the implementation costs and reputational consequences of having multifunction agencies. ${ }^{9}$

In this article, we extend our analysis to consider regulatory leveraging. Assume a competition agency that has significant regulatory power, such as the right to review certain mergers before they are consummated. Pursuant to this authority, the agency determines how quickly mergers are cleared, or whether they can proceed at all. This regulatory power is the functional equivalent of the market power that some private firms enjoy. Further assume that the agency has responsibilities beyond its competition portfolio - say, with regard to privacy and data security. A firm seeks the approval of the agency to merge with another company. What should we think if the agency uses its regulatory power in policy domain A (i.e., merger approval) to extract concessions with respect to policy domain B (i.e., privacy and data security)? Is that a good idea or a

\footnotetext{
${ }^{5}$ See David A. Hyman \& William E. Kovacic, Competition Agencies with Complex Policy Portfolios: Divide or Conquer?, in Competition Law on the Global Stage: David Gerber's Global Competition Law in Perspective 33, 33-34 (Nicolas Charbit \& Elisa Ramundo eds., 2013).

${ }^{6}$ For example, the merger control mechanism in South Africa's competition law obliges the competition authority to account for a variety of public interest considerations. See DAVID Lewis, Enforcing Competition Rules in South Africa: Thieves at the Dinner TABle 111-12 (2012). See also id., at 117-28 (discussing the design and operation of South Africa's public interest test).

7 15 U.S.C. $\S 45(a)(2)$ (2012). The origins and aims of this provision are examined in William E. Kovacic \& Marc Winerman, Competition Policy and the Application of Section 5 of the Federal Trade Commission Act, 76 AnTITRUST L.J. 929, 930-39 (2010).

${ }^{8}$ See Hyman \& Kovacic, supra note 5, at 33, 42; William E. Kovacic \& David A. Hyman, Consume or Invest: What Do/Should Agency Leaders Maximize?, 91 WASH. L. REV. 295 (2016) [hereinafter Kovacic \& Hyman, Consume or Invest]; David A. Hyman \& William E. Kovacic, Can't Anyone Here Play This Game? Judging the FTC's Critics, 83 Geo. WASH. L. REv. 1948, 1973-74, n.151 (2015); David A. Hyman \& William E. Kovacic, Why Who Does What Matters: Governmental Design and Agency Performance, 82 GEO. WASH. L. REv. 1446 (2014) [hereinafter Hyman \& Kovacic, Who Does What]; David A. Hyman \& William E. Kovacic, Institutional Design, Agency Life Cycle, and the Goals of Competition Law, 81 Fordham L. ReV. 2163 (2013); William E. Kovacic \& David A. Hyman, Competition Agency Design: What's on the Menu? 8 Eur. Competition J. 527 (2012).

${ }^{9}$ See, e.g., Hyman \& Kovacic, Who Does What, supra note 8.
} 
bad idea? Does your response differ if the agency is using its regulatory authority in policy domain A to obtain concessions that it could not obtain, or could realize only with great difficulty, if it focused solely on the behavior of the firm in policy domain B? What if the agency is using its regulatory authority in policy domain A to obtain concessions in policy domain $\mathrm{B}$ that would be unconstitutional if it sought to impose them directly? Does it make a difference if the agency has no regulatory authority over policy domain B? What if the agency does not have regulatory authority over policy domain $\mathrm{B}$, but a different agency, which does have that authority, has asked the competition agency to seek the concessions at issue? Stated bluntly, is regulatory leveraging a troublesome problem — or a useful solution?

Part I describes leveraging in the private and public sectors. Part II provides four case studies of public sector leveraging. Part III considers the costs and benefits of regulatory leveraging. Part IV offers several suggestions for increasing the likelihood that leveraging is used for prosocial ends. Part V flags the existence of the converse problem/issue - i.e., leveraging regulators.

\section{LEVERAGING 101}

"Leveraging" refers to one party exploiting a position of power to gain an advantage over a counterparty. ${ }^{10} \mathrm{We}$ introduce the concept of leveraging by describing its application in competition law, and then by describing analogous forms of behavior undertaken by public regulatory agencies.

\section{A. Private Sector Leveraging}

Private sector leveraging occurs when a firm uses market power over Product A to distort rivalry for sales of Product B. ${ }^{11}$ If a firm has market power over Product A, it can harm competition over Product B by "tying" the purchase of the two products together. ${ }^{12}$ Consumers who want Product A can be forced to buy Product B, even if they would not do so otherwise. Similarly, the firm with market power over Product A can

\footnotetext{
${ }^{10}$ See Leverage, Black's Law Dictionary (10th ed. 2014) (defining leverage as "[p]ositional advantage that may well help a person get what he or she wants from others. . ,').

${ }^{11}$ See Keith N. Hylton, Antitrust Law: Economic Theory \& Common Law Evolution 202-12 (2003).

${ }^{12}$ See David S. Evans et al., A Pragmatic Approach to Identifying and Analyzing Legitimate Tying Cases, in Global COMPETITION Policy: ECONOMiC Issues \& IMPACTS 297, 305-06 (David S. Evans \& A. Jorge Padilla eds., 2004) (explaining how tying may assist firms in leveraging market power from one product to another).
} 
protect its position against market entry by firms that make complements that might become substitutes. ${ }^{13}$ Competition law addresses these risks by selectively prohibiting some (but not all) forms of tying, bundling, and loyalty discounts. ${ }^{14}$ More controversially, some competition agencies have targeted the "portfolio effects" of proposed mergers. ${ }^{15}$ These examples make it clear that some forms of private leveraging have anticompetitive consequences, and raise concerns that competition law has addressed.

\section{B. Public Sector (Regulatory) Leveraging}

The public sector analog of private leveraging occurs in several ways. In the main case, an agency uses its gatekeeping power within one policy domain to alter the behavior of firms in other policy domains. ${ }^{16}$ Regulatory leveraging also can take place within a single policy domain, where an agency uses its gatekeeping power with respect to one component of that domain to obtain concessions from firms concerning a separate element of the policy domain. ${ }^{17}$

Regulatory leveraging allows the agency to exploit its gatekeeping authority in several ways. In some instances, leveraging enables the agency to secure results that it might not have been able to achieve otherwise. In others, leveraging permits the agency to attain those results without recourse to other policy tools that the agency regards as more costly or risky to use.

What kind of gatekeeping power makes regulatory leveraging

\footnotetext{
${ }^{13}$ This was essentially the Department of Justice's theory in the Microsoft case, which inter alia involved the claim that Microsoft's bundling of Internet Explorer with Windows 95 and Windows 98 violated Sections 1 and 2 of the Sherman Act. See United States. v. Microsoft Corp., 253 F.3d. 34, 47 (D.C. Cir. 2001); Press Release, U.S. Department of Justice, Justice Department Files Antitrust Suit Against Microsoft for Unlawfully Monopolizing Computer Software Markets (May 18, 1998) ("The complaint . . charges that Microsoft recognized that the success of Netscape's internet browser threatened Microsoft's Windows monopoly on PC operating systems."). On the role of the tying allegations in the Justice Department's suit against Microsoft, see ANDrEW I. GAVIL \& HARRY FIRST, THE Microsoft ANTITRUST CASES 61-66 (2014).

${ }^{14}$ See Robert O’Donoghue \& A. Jorge Padilla, The Law and Economics of Article 82 EC 381-84, 491-511 (2006) (describing application of European Union competition law to bundling, loyalty discounts, and tying). See also Evans, et al., supra note 12, at 299;

HYLTON, supra note 11, at 202-12.

${ }^{15}$ See The Organisation for ECONOMiC Co-operation and Development, Policy Roundtables: PortFolio EFFECTS IN CONGLOMERATE MERgers 19 (2001), http://www.oecd.org/competition/mergers/1818237.pdf. See also Thomas L. Ruffner, Note, The Failed GE/Honeywell Merger: The Return of Portfolio-Effects Theory? 52 DEPAUL L. REV. 1285,1321 (2003) (describing application of portfolio effects theory in European Commission's challenge to General Electric's effort to acquire Honeywell).

${ }^{16}$ See infra Part II.A.

${ }^{17}$ See infra Part II.B-C.
} 
possible? The most obvious form of gatekeeping takes place when the agency has ex ante approval authority over something that the regulated entity wants, such as a license to operate in a given market (e.g., the right to operate a radio station, or the franchise to offer cable TV services) or to introduce a product (e.g., to sell a pharmaceutical). Without the regulator's ex ante approval, the firm cannot offer its intended service or product. A second form of gatekeeping power is created by laws that require firms to notify the regulator in advance of a contemplated measure (e.g., a merger). Such laws require the expiration of a waiting period before the proposed action may be taken. These laws give the regulator an opportunity to study the proposed course of action, subject to a deadline that forces action within a specified time.

In competition law, the second scenario arises frequently in merger control. In 1976, the United States established what has become the leading model for modern merger control by enacting the Hart-Scott-Rodino Antitrust Improvements Act of 1976 ("HSR"). ${ }^{18}$ As implemented by rules promulgated by the Federal Trade Commission, HSR requires the merging parties to provide notice of certain proposed transactions to the FTC, and establishes a mandatory waiting period during which the FTC or the Department of Justice can decide whether to compel the production of additional information. ${ }^{19}$ When the parties have produced the required information, the antitrust agencies have a fixed period of time in which to decide whether to challenge the merger. ${ }^{20}$ The parties cannot proceed until the waiting period expires, or until the antitrust agency indicates that it will not oppose the deal. ${ }^{21}$ One recent survey of global merger practice identifies roughly seventy jurisdictions that have variants of the HSR premerger notification and mandatory waiting period system. ${ }^{22}$

HSR and similar regulatory regimes have transformed merger review from an ex post assessment of completed transactions into ex ante review of proposed deals. ${ }^{23}$ Most merger-related litigation has been replaced by negotiated settlements, resulting in either outright approval,

\footnotetext{
${ }^{18}$ Hart-Scott-Rodino Antitrust Improvements Act of 1976, Pub. L. 94-435, 90 Stat. 1383 (1976) (codified at 15 U.S.C. $§ 18 \mathrm{a}(2012)$ ).

${ }^{19}$ See ABA Section of Antitrust Law, Antitrust Law Developments 394-401 (7th ed. 2012) (discussing the requirements of the HSR mechanism).

${ }^{20} \mathrm{Id}$. at 397-98; Douglas Broder, U.S. ANTITRust LaW AND ENFOrCEMENT: A Practice INTRODUCTION 137 (2010).

${ }^{21}$ BRODER, supra note 20, at 137.

22 Getting the Deal Through: Merger Control 2016, at 450-79 (John Davies, ed., 2016).

${ }^{23}$ For analysis of this transformation, see Spencer Weber Waller, Prosecution by Regulation: The Changing Nature of Antitrust Enforcement, 77 ORE. L. REV. 1383 (1998); E. Thomas Sullivan, The Antitrust Division as a Regulatory Agency: An Enforcement Policy in Transition, 64 WASH. U. L. REV. 997 (1986).
} 
divestitures, or conduct remedies. ${ }^{24}$ The HSR merger approval process is tailor-made for the exercise of regulatory leverage, since firms prefer an expedited resolution, and are willing to make concessions to accomplish that goal. ${ }^{25}$ Stated differently, when time is of the essence - as it is in many mergers - the agency will have considerable regulatory leverage. Of course, if the agency overreaches, the regulated entity may be willing to walk away from the transaction, or force the agency to go to federal district court to enjoin the merger. Thus, there are limits to the concessions an agency can extract. Yet the basic point remains the same: when a regulatory agency controls access to a valuable resource, it can use that power to extract a variety of concessions from regulated entities that want access to that resource.

Perhaps less obviously, agencies can also use "global settlements," which reach beyond the specific controversy they are handling, to obtain leverage over ancillary domains. ${ }^{26}$ If a company wants to put a dispute in policy domain A behind it, it may be open to concessions in policy domain $\mathrm{B}$ - even though the agency would otherwise lack the regulatory authority to impose that result on its own.

Is regulatory leveraging a normal, legitimate, and perhaps inevitable feature of agency design? Or is it the equivalent of "hostage taking," with the regulated entity forced to pay Danegeld in order to be left in peace $?^{27}$ We focus our consideration of that issue with four case studies of regulatory leveraging.

\section{FOUR CASE STUdIES OF REGULATORY LEVERAGING}

As we suggested above, regulatory leveraging can take place in several scenarios. First, a regulator can seek to leverage its power across distinct areas within a single policy domain. Second, a multipurpose agency can leverage power across distinct policy domains within its portfolio of duties. Third, a regulator can use the gatekeeping power of another agency to obtain concessions from a firm that is subject to oversight by both agencies. Fourth, an agency can use a public interest mandate to achieve commitments that are not authorized by more specific legal commands.

\footnotetext{
${ }^{24}$ See Sullivan, supra note 23, at 1001 ("[T] he Antitrust Division has changed from a traditional, litigation-oriented enforcement agency to a regulatory agency. The Antitrust Division, as an economic regulator, has adopted a negotiational rather than adversarial posture.").

${ }^{25}$ BRODER, supra note 20, at 189-90.

${ }^{26}$ ABA Section of Antitrust Law, State Antitrust Enforcement Handbook 215 (2d ed. 2008).

${ }^{27}$ But see Rudyard KiPling, Dane-Geld (A.D. 980-1016), in A KiPLing Anthology: VERSE 184-85 (1922) ("if once you have paid him the Dane-geld. You never get rid of the Dane.")
} 
Below we offer case studies of each scenario.

\section{A. Bosch-SPX: Leveraging Across Two Antitrust Domains}

In 2012, the FTC resolved two matters involving Robert Bosch $\mathrm{GmbH} .{ }^{28}$ The first matter involved Bosch's proposed acquisition of SPX Service Solutions U.S. LLC ("SPX"). ${ }^{29}$ The transaction would have given Bosch a "virtual monopoly in the market for air conditioning recycling, recovery, and recharge (ACRRR) devices." ${ }^{30}$ That issue was resolved with an agreement by Bosch to divest its automotive air-conditioner repair equipment business, and make some licensing commitments. ${ }^{31}$

The same FTC press release went on to announce that the Commission and Bosch had resolved an entirely separate dispute over whether SPX had harmed competition by reneging "on a commitment to license key, standard-essential patents (SEPs) on fair, reasonable, and nondiscriminatory (FRAND) terms. The FTC alleged that SPX reneged on its obligation to license on FRAND terms by seeking injunctions against willing licensees of those patents." 32

Bosch agreed to abandon SPX's claims for injunctive relief, resolving an ancillary matter that long preceded the proposed merger. ${ }^{33}$ The FTC had authority to review Bosch's proposed merger under Section 7 of the Clayton Act, and to challenge SPX's conduct under Section 5 of the FTC Act. ${ }^{34}$

It is not clear from the FTC's press release how these two entirely distinct issues came to be settled simultaneously. ${ }^{35}$ But the fact that they appear in the same press release certainly leads us to believe they were resolved as a package deal. Would the SPX matter have been resolved on the same terms and within the same time frame if the FTC had pursued that matter independently, by pursuing a separate case premised on Section 5 of the FTC Act? Would the SPX matter have been resolved on the same terms and within the same time frame if Bosch did not have a merger pending

\footnotetext{
${ }^{28}$ Press Release, Fed. Trade Comm'n, FTC Order Restores Competition in U.S. Market for Equipment Used to Recharge Vehicle Air Conditioning Systems (Nov. 26, 2012), https://www.ftc.gov/news-events/press-releases/2012/11/ftc-order-restores-competition-usmarket-equipment-used-recharge [hereinafter FTC Vehicle Air Conditioning Systems Press Release].

${ }^{29} I d$.

${ }^{30} I d$.

${ }^{31} I d$.

${ }^{32} \mathrm{Id}$.

${ }^{33}$ Id.

${ }^{34}$ Clayton Antitrust Act, Pub. L. No. 63-212, § 7, 38 Stat. 730, 731-32 (1914) (codified at 15 U.S.C. $\S 18$ (2012)); Federal Trade Commission Act, Pub. L. No. 63-203, § 5, 38 Stat. 717, 719-21 (1914) (codified at 15 U.S.C. § 45(a)(2) (2012)).

${ }^{35}$ See FTC Vehicle Air Conditioning Systems Press Release, supra note 28.
} 
before the FTC? Bosch certainly had a huge incentive to give in on the SPX matter in order to obtain speedy approval of the proposed merger-and FTC personnel knew that. No one at the FTC has to say "nice merger you've got there; it would be a shame if anything was to happen to it," for those seeking agency approval to understand how the game will be played. $^{36}$

\section{B. Data Protection/Privacy and Merger Approval: Cross-Domain Leveraging by a Multipurpose Regulator}

Over the past few years, the way in which private firms use datahow they collect it, how they use it, and how they distribute it to third parties - has become a major policy concern in the United States and abroad. ${ }^{37}$ Should regulatory policies in this space be developed on an industry-wide basis, through notice-and-comment regulation? Or should privacy policy result from enforcement actions against bad actors? Might merger review provide an opportunity for regulatory leverage in this space? The FTC, the principal U.S. data protection authority, ${ }^{38}$ confronted these issues in two merger reviews involving Google - in 2007, when Google sought regulatory approval for its acquisition of DoubleClick, ${ }^{39}$ and in 2010, when the FTC reviewed Google's purchase of AdMob. ${ }^{40}$

In both transactions, agency personnel debated whether the merger review process should include an evaluation of Google's data protection and privacy policies. ${ }^{41}$ The debate was complicated by the fact that

${ }^{36}$ See Monty Python, supra note 1.

${ }^{37}$ On the emergence of privacy as a central U.S. policy concern, see generally Maureen K. Ohlhausen \& Alexander P. Okuliar, Competition, Consumer Protection, and The Right [Approach] to Privacy, 80 AnTITRUST L.J. 121 (2015). On the global dimensions of data collection and privacy, see VIKTOR MAYER-SCHÖNBERGER \& KENNETH CUKIER, BIG DATA 150-84 (2014).

38 See generally Chris Jay Hoofnagle, Federal Trade Commission Privacy LaW and POLICY 145-328 (2016) (discussing development of FTC as principal U.S. privacy regulator). We are currently working on an article that explores how the FTC ended up, partly by choice, but largely by accident, as the nation's primary privacy agency. David A. Hyman \& William E. Kovacic, By Accident or Design? The Future Institutional Framework for U.S. Data Protection and Privacy Regulation (forthcoming 2017) (manuscript on file with authors).

${ }^{39}$ Press Release, Fed. Trade Comm'n, FTC Closes Google/DoubleClick Investigation (Dec. 20, 2007), https://www.ftc.gov/news-events/press-releases/2007/12/federal-tradecommission-closes-googledoubleclick-investigation [hereinafter FTC Google/DoubleClick Press Release].

${ }^{40}$ Press Release, Federal Trade Commission, FTC Closes its Investigation of Google AdMob Deal (May 21, 2010), https://www.ftc.gov/news-events/press-releases/2010/05/ftccloses-its-investigation-google-admob-deal [herinafter FTC Google AdMob Press Release].

${ }^{41}$ See FTC Google/DoubleClick Press Release, supra, note 38; FTC Google AdMob Press Release, supra note 40. 
different units within the FTC were responsible for merger review (i.e., the Bureau of Competition) $)^{42}$ and data protection and privacy (i.e., the Bureau of Consumer Protection). ${ }^{43}$ The FTC clearly had the legal authority to review Google's proposed acquisitions of DoubleClick and AdMob. ${ }^{44}$ It also had the legal authority to investigate Google's data protection and privacy policies. ${ }^{45}$ But agency personnel disagreed on whether the merger review should be used as an excuse/pretext/justification to delve into Google's data protection and privacy policies. ${ }^{46}$

Some agency personnel (most of whom were in the Bureau of Consumer Protection) thought the issue was a no-brainer. ${ }^{47}$ Of course the FTC should take advantage of the fact that Google was seeking to acquire DoubleClick and AdMob to investigate these issues - and use the merger approval process to extract appropriate concessions to ensure that consumers' interests were protected. Others (most of whom were in the Bureau of Competition) were concerned that (i) merger review was supposed to focus on antitrust and harms to competition, rather than serve as a means to achieve the agency's data protection and privacy aims; (ii) opening this particular can of worms would mean that the outcome of a merger review could turn on whether the FTC or DOJ was conducting the evaluation (since the FTC was more concerned with data security and privacy than DOJ); and (iii) by making clear that merger review outcomes could vary significantly depending upon which agency got the file, the FTC's use of the HSR process to implement privacy and data protection policy would lead Congress to reassess the wisdom of having two federal antitrust agencies share merger enforcement authority - an assessment that might lead to the consolidation of all merger-control duties in the DOJ. Ultimately, the FTC did not use the Google-DoubleClick or the Google-AdMob merger review process to extract concessions from Google regarding its data protection and privacy policies. Indeed, the FTC's closing statement in DoubleClick explicitly disclaimed such strategies, noting that "the sole purpose of federal antitrust review of mergers and acquisitions is to identify and remedy transactions that harm competition." 48 The FTC

\footnotetext{
${ }^{42}$ Bureau of Competition, FED. TRADE COMM'N, https://www.ftc.gov/about-ftc/bureausoffices/bureau-competition (last visited June 30, 2016).

${ }^{43}$ Bureau of Consumer Protection, FED. TRADE COMM'N, https://www.ftc.gov/about$\mathrm{ftc} /$ bureaus-offices/bureau-consumer-protection (last visited June 30, 2016).

${ }^{44}$ See 15 U.S.C. $\S \S 18,45(a)(1)-(2)(2012)$.

${ }^{45}$ See 15 U.S.C. $\$ 45(\mathrm{a})(1)-(2)(2012)$.

${ }^{46}$ See FTC Google/DoubleClick Press Release, supra note 39.

${ }^{47}$ As noted previously, one of us (Kovacic) served in various positions at the FTC from 2006-2011 when Google sought regulatory approval to acquire Double Click and AdMob. See supra note *

${ }^{48}$ Fed. Trade Comm'n, Statement Concerning Google/DoubleClick, FTC File No. 0710170, at 2 (Dec. 20, 2007), available at https://www.ftc.gov/system/files/documents/public_statements/418081/071220googledc-
} 
accordingly concluded that it lacked the legal authority to block or condition approval of the transaction on non-antitrust grounds - which would include data protection and privacy grounds. ${ }^{49}$ The closing statement, joined by Chairman Majoras, and Commissioners Kovacic, Leibowitz, and Rosch, also noted that the data protection and privacy issues were not specific to Google-DoubleClick but extended to the entire online advertising marketplace. ${ }^{50}$ As such, using the merger review process to implement data protection and privacy regulation created a significant risk of disparate treatment, and non-uniform enforcement of the law. ${ }^{51}$ Interestingly, although Commissioner Pamela Jones Harbor dissented, she agreed it would be inappropriate to use the merger review process to implement data protection and privacy regulations. ${ }^{52}$

\section{Leveraging Across Policy Domains Occupied by Separate Regulators}

Although the FTC declined to engage in regulatory leveraging to deal with data protection and privacy, other regulators do not share that view. In March 2014, the European Data Protection Supervisor issued an opinion suggesting that European competition authorities should take account of data protection and privacy concerns when deciding whether to approve a merger. ${ }^{53}$ In effect, this would mean that the merger review process will be used as the occasion (and opportunity) to impose substantive privacy regulations on the merging entity. An alternative approach, embraced by the European Commission's Directorate-General for Competition (DG-Comp), is to reframe the competition analysis to take account of data privacy concerns, and examine whether the merger has the

commstmt.pdf.

${ }^{49} I d$.

${ }^{50} I d$. at $1-2$.

${ }^{51}$ See id. at 2 ("Not only does the Commission lack legal authority to require conditions to this merger that do not relate to antitrust, regulating the privacy requirements of just one company could itself pose a serious detriment to competition in this vast and rapidly evolving industry.").

52 Pamela Jones Harbour, Comm'r, Fed. Trade Comm'n, Dissenting Statement Regarding In re Google/DoubleClick, FTC File No. 071-0170 (Dec. 20, 2007), at 10, http://www $\mathrm{ftc.gov/sites/default/files/documents/public \_ statements/statement-}$ mattergoogle/doubleclick/071220harbour_0.pdf. As elaborated in a later work, Commissioner Harbour proposed that privacy should be considered a qualitative dimension of competition. Pamela Jones Harbour \& Tara Isa Koslov, Section 2 in a Web 2.0 World: An Expanded Vision of Relevant Product Markets, 76 AnTITRUST L.J. 769, 773-74 (2010).

${ }_{53}$ See European Data Protection Supervisor, Privacy and Competitiveness in the Age of Big Data: The Interplay Between Data Protection, Competition Law and Consumer Protection in the Digital Economy 22-23, (March 2014),

https://secure.edps.europa.eu/EDPSWEB/webdav/site/mySite/shared/Documents/Consultati on/Opinions/2014/14-03-26_competitition_law_big_data_EN.pdf. 
effect of reducing the ability and willingness of the parties to provide adequate levels of data protection. ${ }^{54}$

The issue is not limited to merger control. In March 2016, Germany's competition agency, the Bundeskartellamt, announced that it had begun an investigation of whether Facebook's privacy practices constitute an "abuse of [dominant] market power" that would violate Germany's antitrust laws. ${ }^{55}$ At an antitrust conference in Washington, D.C., the EC Commissioner for Competition, Margarethe Vestager, spoke approvingly of the German initiative. ${ }^{56}$

The precise motivation for the Bundeskartellamt investigation of Facebook is unclear. We can only speculate about what factors led agency officials to commence the matter. The investigation may reflect a belief that competition law is a suitable tool to force dominant firms to observe privacy law mandates, or to set broader policy for the digital economy. Alternatively, perhaps the Bundeskartellamt embraces the aims of Germany's data protection regime and views competition law as a more effective tool to achieve these aims, compared to the direct application of

\footnotetext{
${ }^{54}$ Eric Auchard, EU Competition Chief to Eye 'Big Data' Concerns in Merger Probes, REUTERS (Jan. 17, 2016), http://www.reuters.com/article/us-europe-data-competitionidUSKCNOUV0ZG. This approach would treat privacy protection as a qualitative dimension of competition, as firms distinguish themselves by providing stronger, or weaker, assurances about how they will handle information obtained about consumer preferences. See also Harbour \& Koslov, supra note 50, at 770-74 (suggesting how privacy issues can be accounted for within an antitrust assessment of competitive effects).

${ }^{55}$ Press Release, Bundeskartellamt, Bundeskartellamt Initiates Proceeding Against Facebook on Suspicion of Having Abused Its Market Power by Infringing Data Protection Rules (Mar. 2, 2016),

http://www.bundeskartellamt.de/SharedDocs/Meldung/EN/Pressemitteilungen/2016/02_03 2016_Facebook.html ("There is an initial suspicion that Facebook's conditions of use are in violation of data protection provisions. Not every law infringement on the part of a dominant company is also relevant under competition law. However, in the case in question Facebook's use of unlawful terms and conditions could represent an abusive imposition of unfair conditions on users. The Bundeskartellamt will examine, among other issues, to what extent a connection exists between the possibly dominant position of the company and the use of such clauses."). Facebook has been the subject of close scrutiny by European privacy regulators. See Sam Schechner \& Natalia Drozdiak, Facebook Faces Privacy Suit in Europe as Scrutiny Increases, WALl ST. J., June 16, 2015, at B5; see also Guy Chazan \& Duncan Robinson, Facebook Hit by German Competition Probe, Fin. TIMES (Mar. 2, 2016), http://www.ft.com/intl/cms/s/0/1f4afa34-e05e-11e5-96b79f778349aba2.html\#axzz45ztsHvWq. ${ }^{56}$ See Jeff Zalesin, Attys Must Flag Problems in M\&A, Enforcers Say, LAw360 (Apr. 8, 2016), http://www.law360.com/articles/782405/print?section=competition ("Vestager said that Germany's current antitrust investigation into Facebook Inc.'s data protection practices could make 'a very valuable contribution' to the understanding of how privacy and competition interact."); see also Jeff Zalesin, EU Embraces Support Role in Facebook Antitrust Probe, LAw360 (Mar. 7, 2016), http://www.law360.com/articles/768063/euembraces-support-role-in-facebook-antitrust-probe.
} 
German privacy law by the country's privacy regulators. ${ }^{57}$ Finally, the Facebook matter could be a turf battle - an effort by the Bundeskartellamt to preempt efforts by German privacy regulators to achieve greater control over the digital economy and its leading high technology participants.

Whatever the explanation turns out to be, the Facebook investigation is a striking example of the use of competition law to enforce obligations that originate in non-antitrust domains - in this instance, data protection. The Bundeskartellamt's announcement of the Facebook inquiry disavowed the use of competition law to treat "every law infringement ... [by] a dominant company" as a competition law violation.$^{58}$ Even so, one can imagine many instances in which a dominant firm's misconduct (e.g., a violation of laws governing environmental protection) injures consumer interests, and distorts consumer choice, by enabling the dominant firm to use noncompliance with other laws to gain a competitive advantage (specifically, the avoidance of costs that would be incurred to comply) over rivals that obey the rules. In effect, this would make the competition agency the backstop enforcer of a potentially large collection of other laws, at least with respect to dominant enterprises. ${ }^{59}$

One additional example of leveraging across agencies comes from the U.S., and involves the Consumer Financial Protection Bureau ("CFPB"). In 2013, Ally Financial was seeking approval from the Federal Reserve and the Federal Deposit Insurance Corporation to convert from a bank holding company to a financial holding company. ${ }^{60}$ It was also being investigated by the CFPB, an independent bureau located within the

57 Privacy is a fundamental human right under EU law. See OrLA LYNSKEy, ThE Foundations of EU Data PRotection LAW 8-9 (2015) (setting out the foundations and content of EU data protection law). For this reason, one might argue that all competition authorities within the EU, at the Commission level and within the member states, have an obligation to account for privacy in applying competition law. We are grateful to Orla Lynskey for this point.

${ }_{58}^{5}$ See Bundeskartellamt, supra note 53.

59 The full implications of such an approach were suggested in an extraordinary proposal, advanced by FTC Chairman Michael Pertschuk in the late 1970s, that the Commission might use its authority (to prohibit unfair methods of competition) to challenge noncompliance with legal obligations governing environmental protection, immigration, and worker safety. The FTC never implemented this theory of enforcement, but Pertschuk's proposal starkly framed the question of when noncompliance with other regulatory commands should serve as a basis for antitrust liability. This episode is analyzed in William MacLeod et al., Three Rules and a Constitution: Consumer Protection Finds Its Limits in Competition Policy, 72 AnTITRUST L.J. 943, 952-54 (2005).

${ }^{60}$ Yuka Hayashi, Consumer Watchdog Pushed Discrimination Case on Vulnerable Firm: Report, Wall ST. J. (Nov. 24, 2015), http://www.wsj.com/articles/consumer-watchdogpushed-discrimination-case-on-vulnerable-firm-report-1448404301. See also Rachel Witkowski, CFPB Overestimates Potential Discrimination, Documents Show, Am. BANKer (Sept. 17, 2015), http://www.americanbanker.com/news/law-regulation/cfpb-overestimatespotential-discrimination-documents-show-1076742-1.html. 
Federal Reserve. ${ }^{61}$ Although the CFPB has no regulatory authority over auto dealers, ${ }^{62}$ it decided to investigate whether the loan portfolios of indirect auto lenders such as Ally indicated that auto dealers were offering less favorable terms to minority borrowers. ${ }^{63}$

According to the former CEO of Ally, the CFPB "threatened to derail [Ally's] efforts to obtain key regulatory approvals if it didn't agree to settle," by paying $\$ 100$ million, and begin offering below-market rates to minorities. ${ }^{64}$ He complained that Ally had been "strong-armed" by a regulator that "absolutely knew they had tremendous leverage over us," and was trying to change industry policy with a trumped-up case. ${ }^{65}$

Internal CFPB memos confirm that agency personnel knew that Ally needed to obtain regulatory approval, and the impending deadline to obtain that approval gave Ally a very strong incentive to settle its dispute with the CFPB ${ }^{66}$ Absent the need to obtain approval from the Federal Reserve, Ally could have forced the CFPB to prove its case in court-and there were major weaknesses in the CFPB's case. ${ }^{67}$ It is impossible to know

\footnotetext{
${ }^{61}$ We address the unusual institutional status of the CFPB in Hyman \& Kovacic, Why Who Does What Matters, supra note 8, at 1487-90.

${ }^{62}$ See 12 U.S.C. $\$ 5519$ (2012).

${ }^{63}$ Hayashi, supra note 58.

${ }^{64}$ Paul Sperry, Bank CEO Reveals How Obama Administration Shook Him Down, N.Y. PosT (Feb. 21, 2016), http://nypost.com/2016/02/21/bank-ceo-reveals-how-obamaadministration-shook-him-down ("The former CEO of Ally Financial Inc. says the Obama administration abused its power by holding the bank's business hostage in order to coerce a record settlement of 'trumped-up' racism charges and push profit-killing new regulations on the entire auto-lending industry .... . Michael A. Carpenter, who helmed Detroit-based Ally from 2009 to 2015, complained in an exclusive interview that Obama's powerful consumer watchdog agency threatened to derail the bank's efforts to obtain key regulatory approvals if it didn't agree to settle the allegations out of court.").

${ }^{65} I d$.

${ }^{66}$ Hayashi, supra note 60; Witkowski, supra note 60.

${ }^{67}$ Sperry, supra note 64 (noting the former CEO asserted "we would have fought the CFPB's trumped-up accusations in every court in the land" if Ally hadn't needed to obtain regulatory approval.) The weaknesses included relying on decidedly imperfect proxies to determine whether a particular consumer was a minority, and the CFPB's failure to take account of credit scores in evaluating loan terms. Witkowski, supra note 58. Lending new meaning to the phrase "good enough for government work," the CFPB argued it was better to over-estimate disparities than to under-estimate them. Id. So much for Blackstone's observation, "better that ten guilty persons escape than that one innocent suffer." See Alexander Volokh, $n$ Guilty Men, 146 U. PA. L. REV. 173, 174 (1997) (quoting 4 WiLliam Blackstone, COMMENTARIES *352). Similarly, the CFPB argued that credit ratings did not "reflect a legitimate business need." In re Ally Fin. Inc., 2013 CFPB Admin. Proc. LEXIS 125 at $\mathrm{P} 26$

(Dec. 20, 2013) (Consent Order). It also sought damages for emotional distress. Sean Higgins, Consumer Bureau Overestimating Numbers Hurt by Discrimination, WASHINGTON EXAMINER (Sept. 18, 2015) http://www.washingtonexaminer.com/consumer-bureauoverestimating-numbers-hurt-by-discrimination/article/2572419. It seems unlikely the CFPB would fare well if it took these aggressive positions in actual litigation before an Article III
} 
how the counterfactual would have played out, but it seems extraordinarily unlikely the CFPB would have been able to extract $\$ 100$ million and a change in Ally's business practices - let alone do so under the same time frame-except under conditions that gave the CFPB an extraordinary degree of regulatory leverage.

\section{Leveraging with a "Public Interest" Mandate}

Many statutes delegate expansive regulatory authority by requiring an agency to attend to the "public interest" in making decisions. ${ }^{68}$ For example, in evaluating proposed transactions involving licenses, the Federal Communications Commission is required to evaluate whether the transaction will serve "the public interest, convenience, and necessity." ${ }^{\text {"I }}$ In reviewing mergers, state public utility commissions operate under replicas of the federal public interest rules, and can use their gatekeeping powers to obtain various concessions involving community services. ${ }^{70}$

These "public interest" standards make it easy for agencies to engage in regulatory leveraging. ${ }^{71}$ The FCC recently used the merger review process to strong-arm Charter Communications to "live up to stringent requirements that don't apply to its bigger rivals," including net neutrality standards that the FCC has been unable to impose through direct regulation. ${ }^{72}$ Over the past decade, the FCC has used this strategy to impose

judge.

${ }^{68}$ For example, a number of jurisdictions have incorporated a public interest test in the merger control provisions of their competition laws. Organisation for Economic Cooperation and Development, Public Interest Considerations in Merger Control, http://www.oecd.org/daf/competition/public-interest-considerations-in-merger-control.htm (last visited June 30, 2016).

${ }^{69} 47$ U.S.C. $\S \S 214(\mathrm{e})(2) \& 310(\mathrm{~d})$ (2012). See also Jon Sallet, FCC Transaction Review: Competition and the Public Interest, FCC Blog (Aug. 12, 2014, 12:39 PM),

https://www.fcc.gov/news-events/blog/2014/08/12/fcc-transaction-review-competition-andpublic-interest.

${ }^{70}$ See Erik Filipink, Serving the "Public Interest"-Traditional vs Expansive Utility

Regulation 3 (Nat'l Reg. Research Inst. Working Paper, Report No. 10-02, 2009), http://www.energycollection.us/Energy-Regulators/Serving-Public-Interest.pdf.

${ }^{71}$ See, e.g., Brendan Sasso, How Mega-Mergers Give the FCC Stealth Power for Net Neutrality, ATLANTIC (May 29, 2014),

http://www.theatlantic.com/politics/archive/2014/05/how-mega-mergers-give-the-fccstealth-power-for-net-neutrality/456969.

${ }^{72}$ Shalini Ramachandran and John D. McKinnon, Regulators Recommend Approval of Charter-Time Warner Cable Deal, Wall St. J., (Apr. 25, 2016),

http://www.wsj.com/articles/regulators-recommend-approval-of-charter-time-warner-cabledeal-1461611989 ("Under a deal with the U.S. Justice Department and Federal

Communications Commission, Charter agreed to abandon for seven years several common industry practices that the government feared could threaten the growth of rival online video providers such as Netflix Inc. and Hulu. The company agreed not to impose data caps or charge broadband Internet customers based on data usage, practices that have riled 
net neutrality constraints on AT\&T, Verizon, BellSouth, Comcast, and NBC. ${ }^{73}$ The FCC has also used regulatory leveraging in other domains: two decades ago, the chairman of the FCC used the merger review process to strong-arm Westinghouse into increasing the number of hours devoted to children's educational programming on CBS. ${ }^{74}$

It is not just the federal government that takes advantage of regulatory leveraging. In March 2016, the District of Columbia Public Service Commission conditioned its approval of the Exelon-Pepco merger on a host of ancillary provisions. ${ }^{75}$ The public service commission had rejected the transaction twice previously, ${ }^{76}$ but reversed field once the parties provided a sufficiently large inducement to do so - in the form of a commitment to relocate certain offices to D.C.; the hiring of unionized workers; and at least \$1.9 million in annual average charitable contributions to organizations located in D.C. or benefiting D.C. residents. ${ }^{77}$

\section{BENEFITS AND COSTS OF REGULATORY LEVERAGING}

To make the benefits and costs of regulatory leveraging more concrete, imagine that you represent a multinational entity that has proposed a substantial merger. You arrive at a meeting with personnel from the DOJ Antitrust Division to discuss the merger. You sit down, and find a bunch of people sitting in the room. You say, "I recognize some of the people here. We've had discussions with them. Here is the front office from the antitrust division. Here are the case handlers. But can you introduce me

customers. Charter will also be required to build out its broadband access to two million homes, which would compel it to compete against other cable companies in some markets, according to a person familiar with the matter.").

${ }^{73}$ Marvin Ammori, Here's How Charter Will Commit to an Open Internet, WIRED (June 25, 2015) http://www.wired.com/2015/06/heres-charter-will-commit-open-internet.

${ }^{74}$ Edmund L. Andrews, FCC Approval Seen Today For Westinghouse-CBS Deal, N.Y. TiMES, (Nov. 22, 1995), http://www.nytimes.com/1995/11/22/business/the-media-businessfcc-approval-seen-today-for-westinghouse-cbs-deal.html. Interestingly, there was an internal dispute within the agency on this issue, with the chairman insisting on linking approval of the deal to the pledge to increase children's programming, and three commissioners insisting that the FCC should make it clear that "it was in no way demanding that CBS or

Westinghouse meet any quantitative requirements for children's programming as a condition of approval." Id.

${ }^{75}$ See Ben Nuckols, District Of Columbia Regulators Voted For A Second Time Friday To Reject A Proposed \$6.8 Billion Merger Between Power Companies Exelon And Pepco, But They Said The Deal Would Go Forward If New Conditions Are Met, Associated Press, Feb. 26, 2016, available at http://www.usnews.com/news/business/articles/2016-02-26/dcregulators-reject-exelon-pepco-deal-but-could-reconsider.

${ }^{76}$ Thomas Heath \& Aaron C. Davis, D.C. Panel Backs Pepco-Exelon Merger, WAsH. Post, Mar. 24, 2016, at B1.

${ }^{77}$ In re Joint Application of Exelon Corp. et al., Pub. Serv. Comm'n. of the Dist. of Columbia, Order No. 18148 ฯ CC, DD, HH (Mar. 23, 2016), available at http://wtop.com/wp-content/uploads/2016/03/PSC-order-Pepco-Exelon.pdf. 
to the rest of the people in the room?" The responses come back fast and furious. "I'm from the DOJ Tax Division." "I'm from the DOJ Civil Rights Division." "I handle government contracts matters for DOJ's Civil Division." "I'm from the EEOC." "I'm from the CFPB." "I'm from the EPA."

Understandably enough, you respond, "What are these people doing here? I'm here to discuss our merger - and just the merger. Those disputes are handled by other lawyers. I don't know anything about them." The head of the merger review team responds, "Well, we're going to talk about the merger - but we've got a whole lot of other issues that we'd also like to resolve with your client. All those other loose ends are getting in the way of our ability to analyze the proposed merger. The Attorney General has instructed me to tell you that if you're willing to concede each and every one of these other matters, we can wrap everything up right now, and get your merger out the door by the end of the week. Or your client can litigate with all of us over these issues - and it will take as long as it takes. But the merger won't be considered until everything else is resolved. It's your choice."

How would you react? What arguments would defenders of regulatory leveraging make in response? We now turn to those issues.

\section{A. Benefits/Advantages}

The most obvious benefit of regulatory leveraging is that it promotes more comprehensive settlements. Going back to our first case study (Bosch-SPX), the FTC already had an open file on SPX, and Bosch then came to the FTC with the proposed merger. ${ }^{78}$ Isn't it more efficient to enter into one global settlement instead of maintaining two separate proceedings? If there are benefits in settlement (and there are), more comprehensive settlements must be better still.

Second, depending on the statutory language employed, leveraging may be an authorized delegation of congressional authority to deal with difficult problems in a flexible way. Stated differently, Congress used "public interest" language to give the agency a hammer that could be deployed when a regulated entity comes to the agency for merger approval. ${ }^{79}$ But the agency can only use the hammer in carefully defined circumstances. The regulated entity can always walk away from the merger, and continue fighting about the ancillary matter(s). This structure keeps the agency from expanding its regulatory leverage beyond any given

${ }^{78}$ See supra Part II.A.

${ }^{79}$ See generally Filipink, supra note 68 (identifying various ways in which the "public interest" standard has been used by regulators to reach issues that are not typically understood to be within the regulator's jurisdiction). 
transaction, while giving it the flexibility to solve problems without going through the drudgery of rulemaking, or starting a separate case.

Even when the agency operates without the benefit of a public interest mandate, leveraging might be viewed as an admirable example of administrative adaptability and creativity. A regulator could defend its unwillingness to address a serious problem by pointing to the limits of its powers, and by interpreting those powers in a cramped way that justifies passivity. By contrast to this cautious view of public administration, the regulator that leverages its powers to solve difficult problems is being inventive and entrepreneurial. And if the agency goes too far, the courts and the legislature stand ready to protect the rule of law.

\section{B. Costs/Disadvantages}

Regulatory leveraging also involves real risks and disadvantages. For starters, regulatory leveraging leads to less disciplined decisionmaking by governmental agencies. Substantive antitrust law governs merger reviews, ${ }^{80}$ but regulatory leveraging encourages agencies to ignore or downgrade these controls. The result is the discounting of both process and substance, in favor of the unimpeded pursuit of more nebulous (and often contestable) goals. Among other consequences, this comes at a considerable cost in predictability for affected commercial parties.

Second, regulatory leveraging leads to decisionmaking that is less transparent and less accountable. Merger review rarely ends up in court, ${ }^{81}$ so agency leadership need only persuade itself that its "wish list" is worth pursuing. Firms badly want to obtain immediate approval of their mergers, ${ }^{82}$ so agency leadership has them over a barrel. Because the "wish list" of desired concessions is achieved through settlement, in many jurisdictions it is, by definition, not subject to appeal.

Third, if multiple agencies handle merger review, the agency that uses regulatory leveraging may place itself at a disadvantage. Currently, the FTC and DOJ both conduct merger reviews. ${ }^{83}$ The two agencies allocate matters between each other chiefly on the basis of recent experience with specific industries. Once word gets around that the FTC (and only the FTC) is engaging in regulatory leveraging, industries that fall within the FTC's purview likely will complain to Congress. If that happens, Congress is likely to reexamine the logic of having two agencies in the merger review space. Certainly, FTC personnel were well aware of this risk when they

\footnotetext{
${ }^{80}$ See, e.g., 15 U.S.C. $\$ 18$ (2012).

${ }^{81}$ See BRODER, supra note 20, at 189-90 ("As a practical matter, the threat of such a suit, or the filing of the complaint, is often enough to dissuade parties from proceeding at all.").

${ }^{82}$ See id.

${ }^{83}$ Id. at 189.
} 
were considering whether to use leveraging in evaluating GoogleDoubleClick and Google-AdMob. ${ }^{84}$

Fourth, regulatory leveraging can be used for "good" or "evil." Privacy and data security standards don't have an obvious ideological or partisan valence - but would people be quite so complacent about regulatory leveraging if they knew that the competition agency was going to be run by their worst enemy? Stated more concretely, what if the competition agency demanded one or more of the following as a condition of approving a merger involving the listed companies:

*Apple had to agree to unlock any iPhone provided to it by the Department of Homeland Security, the Central Intelligence Agency, the Federal Bureau of Investigation, the Drug Enforcement Administration, or the Bureau of Alcohol, Tobacco, Firearms and Explosives.

*Verizon had to agree to provide immediate and unrestricted access to the text messages associated with any subscriber's number, without requiring a warrant or notifying the subscriber, upon request by any federal, state, or local governmental entity.

*Google had to create a backdoor to Gmail, and turn it over to the National Security Agency.

*Salesforce had to fire its CEO, who was the ringleader of corporate attempts to pressure Republican state lawmakers on social issues. ${ }^{85}$ For every dollar Salesforce had to pay its CEO to go away, it had to pay ten times that amount to support the Tea Party.

*PayPal had to reverse its decision to cancel a $\$ 3.6$ million operations center in Charlotte, North Carolina, in response to the state's enactment of the "Public Facilities Privacy and Security Act." ${ }^{86}$ PayPal also had to spend at least twice that amount endowing a center at the University of North Carolina for the study of the War of Northern Aggression. Finally, each member of PayPal's board and senior management (including vegetarians, vegans, and those with

\footnotetext{
${ }^{84}$ See supra Part II.B.

${ }^{85}$ Monica Langley, Salesforce's Marc Benioff Has Kicked Off New Era of Corporate Social Activism, WALL ST. J. (May 2, 2016), http://www.wsj.com/articles/salesforces-marc-benioffhas-kicked-off-new-era-of-corporate-social-activism-1462201172.

${ }^{86}$ Susanna Kim, Boycott Over North Carolina's LGBT 'Bathroom Law' May Be Gaining Traction as Economic Fallout Grows, ABCNEws (Apr. 13, 2016), http://abcnews.go.com/Business/boycott-north-carolinas-lgbt-bathroom-law-gainingtraction/story?id=38367656. The law bans people from using bathrooms that don't match the sex indicated on their birth certificates.
} 
religious objections to eating pork) had to spend a week eating only Carolina BBQ and drinking sweet tea, after which they had to personally hand-write a five-page essay on the virtues of that diet. ${ }^{87}$

*All companies seeking merger approval had to make large contributions to foundations created and administered by the antitrust regulators. The funds may be used for any purpose the regulators deem appropriate.

\section{How do you like regulatory leveraging now?}

Fifth, once it becomes clear that regulatory leveraging is what wellestablished first-world regulators do, it will be much more difficult to persuade competition authorities in other nations not to take advantage of the same opportunities. This will prove to be a particularly challenging problem in countries where competition authorities are struggling to deal with political interference in their decision-making process, and outright corruption.

Finally, because regulatory leveraging is merger-specific, it creates firm-specific discontinuities in the applicable law. Only firms that have had a merger reviewed by the agency will be subject to regulatory leverageand the details of the resulting settlements may well vary, depending on the priorities of agency leadership at the time the merger was reviewed, and the extent to which firm management was willing to give away the store to get the merger approved. Of course, regulatory leveraging during the merger review process can deliver a clear signal about the agency's preferencesand firms might fall into line voluntarily, even if they do not anticipate pursuing a merger anytime soon. ${ }^{88}$ But some firms may resist, and others may simply ignore the strong hints being dropped by the agency. In combination, these dynamics are likely to create significant firm-specific discontinuities in the rule of law. ${ }^{89}$ Those discontinuities will have bad

\footnotetext{
${ }^{87}$ Obviously, the antitrust agencies could not constitutionally require PayPal's Board of Directors to each complete a 5-page essay extolling the virtues of sweet tea and Carolina BBQ. See West Virginia State Bd. of Educ. v. Barnette, 319 U.S. 624, 642 (1943) ("If there is any fixed star in our constitutional constellation, it is that no official, high or petty, can prescribe what shall be orthodox in politics, nationalism, religion, or other matters of opinion or force citizens to confess by word or act their faith therein.").

${ }^{88}$ See Jerry Brito, “Agency Threats" and the Rule of Law: An Offer You Can't Refuse, 37 HaRV. J. L. Pub. Pol’y 553, 553 (2012); Tim Wu, Agency Threats, 60 Duke L. J. 1841 1841-42 (2011).

${ }^{89}$ There is some evidence that the CFPB's campaign against discriminatory auto lending has had exactly this result. Rachel Witkowski, The Inside Story of the CFPB's Battle Over Auto Lending, AM. BANKER (Sep. 24, 2015), http://www.americanbanker.com/news/lawregulation/the-inside-story-of-the-cfpbs-battle-over-auto-lending-10769401.html?zkPrintable=1\&nopagination $=1$.
} 
results, including impeding the development of a robust market for mergers and acquisitions.

\section{SQUARING THE REgUlatory LEVERAGING CIRCLE}

How should the conundrum of regulatory leveraging be addressed? Following Professor James Q. Wilson, we propose "a few modest suggestions that may make a small difference." 90

\section{A. Express Delegations of Authority}

If Congress wants agencies to engage in regulatory leveraging, it should explicitly authorize the process, and identify some boundaries. Should agencies only engage in leveraging for substantive areas of law within their zone of regulatory authority, or should they be allowed to range more widely? If agencies range beyond their own zone of regulatory authority, should it be only at the request (or at least with the concurrence) of the agency that is actually responsible for that substantive area? What criteria should an agency employ in deciding whether to engage in regulatory leveraging? How long can an agency hold up a regulated entity, seeking to get concessions? What counts as a reasonable basis for holding up the regulated entity? Can an agency demand something that it cannot directly impose, either because of limitations in its own regulatory authority, or because doing so would be unconstitutional? And so on.

Simply stated, an express congressional delegation of authority would go a long way in legitimating the use of regulatory leveraging. The absence of an express delegation of authority should be understood as equally dispositive in the opposite direction. Expressio unius est exclusio alterius.

\section{B. More Transparency}

Agencies should be much more explicit about what they are doing in the regulatory leveraging space. This will simultaneously discipline their use of regulatory leveraging, and force them to articulate and justify their use of this tool. If an agency believes that regulatory leveraging is a sensible way of solving a problem it confronts, the agency should forthrightly explain and justify its actions. If an agency isn't willing to brag about what it is doing, it probably shouldn't be doing it. Sunlight may not be a perfect disinfectant, but if regulators can't stand the heat, they should get out of the kitchen.

\footnotetext{
${ }^{90}$ James Q. Wilson, Bureaucracy: What Government Agencies Do and Why They Do Iт 369 (1989).
} 


\section{Fewer Gates}

More gates means more gatekeepers - and more opportunities for regulatory leveraging. The obvious solution is to be exceedingly careful about creating new gates, and revisit the necessity of existing gates. So, before creating any new gates, legislators should explicitly decide whether they are absolutely necessary - and if so, whether the responsible agency may engage in regulatory leveraging, and the circumstances under which leveraging can occur. Legislators should also "sunset" all gates, forcing routine reconsideration of the necessity of each gate.

\section{Better Norms}

Regulatory leveraging is, at best, a third-best solution for dealing with policy problems. In some instances, internal political dynamics will discourage the use of regulatory leveraging. ${ }^{91}$ But a robust norm against the use of regulatory leveraging will play a useful backup role in disciplining the inappropriate exercise of gatekeeping authority.

\footnotetext{
${ }^{91}$ See supra notes 36-50, 67 and accompanying text (discussing internal political constraints on use of regulatory leveraging by the FTC and FCC).
} 


\section{E. Ex Post Review}

As always, more data would be helpful. We don't know how often regulatory leveraging takes place, the circumstances under which it occurs, and how effective (or ineffective) it actually is. There have been complaints about the exercise of regulatory leverage by multiple entities within the federal government, including the CFPB $,{ }^{92} \mathrm{FCC},{ }^{93} \mathrm{FDA},{ }^{94}$ and the Department of Education. ${ }^{95}$ At the state and local level, many "takings" cases involve similar instances of regulatory exactions, including the compelled surrender of land to create bicycle or pedestrian paths, ${ }^{96}$ and cash settlements to be controlled and disbursed by the regulators. ${ }^{97}$ And there are the long-standing arguments over "unconstitutional conditions" and the spending power. ${ }^{98}$

${ }^{92}$ See supra notes 58-61 and accompanying text.

${ }^{93}$ See Sasso, supra note 69.

${ }^{94}$ More specifically, the FDA's prohibition of off-label marketing is a clear example of the FDA leveraging its authority over drug labeling. See Peter J. Henning, FDA's 'Off-Label' Drug Policy Leads to Free Speech Fight, N.Y. Times (Aug. 10, 2015),

http://www.nytimes.com/2015/08/11/business/dealbook/fdas-off-label-drug-policy-leads-tofree-speech-fight.html?_r=0. Similarly, although the FDA is prohibited from regulating the practice of medicine, it has used its authority over drug approvals to limit the circumstances under which certain drugs can be prescribed. See 15 U.S.C. § 396 (2012) ("Nothing in this chapter shall be construed to limit or interfere with the authority of a health care practitioner to prescribe or administer any legally marketed device to a patient for any condition or disease within a legitimate health care practitioner-patient relationship."). See also PAUL D. Clement \& Laurence H. Tribe, American Clinical Laboratory AsSociation White Paper: Laboratory Testing Services, As the Practice of Medicine, Cannot Be Regulated as Medical Devices 11-12 (2015) available at http://www.acla.com/wpcontent/uploads/2015/01/Tribe-Clement-White-Paper-1-6-15.pdf (highlighting

"Congress['s] longstanding reluctance to interfere with the practice of medicine, which is underscored by an express statutory disclaimer of such inference."). The first form of leveraging is likely inconsistent with the Constitution; the second form of leveraging is likely inconsistent with the FDA's enabling legislation.

${ }^{95}$ Emma Brown, U.S. Senator: Education Dept. Overstepped Authority on Sexual Assault Complaints, WASH. Post (Jan. 7, 2016),

https:/www.washingtonpost.com/news/education/wp/2016/01/07/u-s-senator-educationdepartment-overstepped-authority-on-sexual-assault-complaints/.

${ }^{96}$ Dolan v. City of Tigard, 512 U.S. 374, 377 (1994); Nollan v. California Coastal Comm'n, 483 U.S. 825, 831-32 (1987).

${ }^{97}$ City of New York v. 17 Vista Assocs., 642 N.E.2d 606, 607 (N.Y. 1994) (“After the Institute presented its case for an exemption, the City, . . 'made it clear' that the exemption would not be granted unless the Institute and Vista each made a substantial payment to the City to benefit the homeless. Resolution of the Institute's entitlement to the exemption would have taken considerable time due to the need for an independent investigation, and the Institute allegedly needed the proceeds of the sale immediately to remain in operation . . . the City, therefore, decided to grant the Institute the exemption, without conducting the usual independent evaluation, provided Vista paid $\$ 500,000$ into a trust created to provide low- and middle-income housing without restriction to seamen. The Institute was also to contribute $\$ 1,000,000$ from the proceeds of the sale to the trust, known as the 15 State Street 
That said, we don't know nearly enough about the prevalence and results of regulatory leverage. Only a consistent practice of ex post review can cast light on these issues.

\section{LEVERAGING REGULATORS}

To this point, we have focused on regulators leveraging private entities. But, under some circumstances, private parties may be able to leverage regulators. We intend to address that issue at greater length in another article -- so we limit our analysis of leveraging regulators to one recent high profile example. As part of its review of the proposed merger between Aetna and Humana, the DOJ asked Aetna what the consequences would be if the merger was not approved. Aetna's CEO responded in a July 5, 2016 letter as follows:

Housing Trust, of which two named plaintiffs, City officials, were to serve as trustees.").

${ }^{98}$ See generally Richard A. Epstein, BARgaining With the StATE 1-12 (1993); Richard A. Epstein and Mario Loyola, The United State of America, Atlantic (July 31, 2014), http://www.theatlantic.com/politics/archive/2014/07/the-federal-takeover-of-stategovernments/375270/ 
Our analysis to date makes clear that if the deal were challenged and/or blocked we would need to take immediate actions to mitigate public exchange and ACA small group losses. Specifically, if the DOJ sues to enjoin the transaction, we will immediately take action to reduce our 2017 exchange footprint.

We currently plan, as part of our strategy following the acquisition, to expand from 15 states in 2016 to 20 states in 2017. However, if we are in the midst of litigation over the Humana transaction, given the risks described above, we will not be able to expand to the five additional states.

In addition, we would also withdraw from at least five additional states where generating a market return would take too long for us to justify, given the costs associated with a potential breakup of the transaction. In other words, instead of expanding to 20 states next year, we would reduce our presence to no more than 10 states. $^{99}$

Stated differently: "Nice exchanges you've got here. It would be a shame if anything was to happen to them." 100

Why would this attempt at leveraging regulators have any traction? DOJ enforces the antitrust law. It doesn't care whether Aetna participates in the public exchanges created by the Patient Protection and Affordable Care Act ("PPACA"). But, the Department of Health and Human Services ("HHS") and the White House care a great deal about the viability of the public exchanges. PPACA (also known as "Obamacare" and as the "Affordable Care Act") was the signature domestic political achievement of the Obama administration -- and the public exchanges were (and are) an essential part of that initiative. The public exchanges were already facing significant difficulties because other insurers had either withdrawn or had issued threats/promises to do so. ${ }^{101}$ Those difficulties would be dramatically increased if Aetna pulled the plug on continued participation. ${ }^{102}$

${ }^{99} \mathrm{http}$ ///big.assets.huffingtonpost.com/AetnaDOJletter.pdf

${ }_{100}$ See supra note 1 , and accompanying text.

101 Anthem made a similar threat/promise regarding the approval of its proposed merger with Cigna. Paul Demko, Anthem links Obamacare expansion with approval of Cigna acquisition, Politico, July 28, 2016, at http://www.politico.com/story/2016/07/anthem-links-obamacare-expansion-with-approvalof-cigna-acquisition-226374. Humana had previously made a more veiled threat/promise. Bruce Japsen, Humana May Withdraw From Obamacare Exchanges, Forbes, Feb. 10, 2016, at http://www.forbes.com/sites/brucejapsen/2016/02/10/obamacare-losses-for-humana- 
In the end, Aetna's attempt to leverage the regulators did not succeed. DOJ challenged the Aetna-Humana merger. ${ }^{103}$ Aetna responded by dropping its exchange operations in 11 states. That move doubtless caused considerable consternation at HHS and the White House -- but that was not enough leverage to get HHS and the White House to force DOJ to back off. ${ }^{104}$

Of course, the success or failure of any given attempt at leveraging regulators is not the issue. What matters is that this is a game that both sides can play. Those who don't like the leveraging of regulators - and use words like "blackmail," "extortion," and "strong-arming" to describe such conduct should at least consider the "sauce for the gander" implications of their disdain.

\section{CONCLUSION}

Regulators like leverage - and some of the time, it is the only available solution to a particular problem. But regulatory leverage raises very real risks and costs, which counsel for considerably greater caution than regulatory agencies have shown to date. Unless properly disciplined, regulatory leveraging becomes lawlessness.

Some of the time, regulatory leveraging is a problem. And, some of the time, regulatory leveraging is the only available solution. This is not the kind of scenario that lends itself to a simple fix, over and above the suggestions we offer in Part IV.

mean-potential-withdrawal-in-2017/\#7abca6466761. And, United Health Care had also announced that it was dramatically reducing its involvement in the public exchanges. Paul R. La Monica, United Healthcare to exit most Obamacare, CNN Money, Apr. 19, 2016, at http://money.cnn.com/2016/04/19/investing/unitedhealthcare-obamacare-exchanges-aca/.

${ }^{102}$ Bob Bryan, Now We Know the Real Reason Aetna Bailed on Obamacare, Business Insider, Aug. 17, 2015, at http://www.businessinsider.com/aetna-humana-merger-reason-forleaving-obamacare-2016-8 ("The move was seen as a huge blow to the future of the act, making Aetna the third large insurer, after United Healthcare and Humana, to significantly reduce its Obamacare business.")

${ }^{103}$ DOJ also challenged the Anthem-Cigna merger. Both of those challenges are pending as this article goes to press.

${ }^{104}$ See Megan McArdle, Aetna's Retreat From Obamacare is More Than It Seems, Bloomberg View, Aug. 16, 2016, at https://www.bloomberg.com/view/articles/2016-0816/aetna-s-retreat-from-obamacare-is-more-than-it-seems ("The calculation is further complicated by the fact that the exchanges and the mergers are regulated by different agencies. Health and Human Services ultimately oversees exchange operations, while the attorney general is the one trying to block the mergers. They both work for the same president, of course. But it would not be the first time that internecine battles between different parts of the same government further complicated an already complicated game.") 